\title{
Second Congress
}

$\mathbf{P}$ lant molecular biology is an international discipline with major concentrations of active investigators on four continents and many individual practitioners throughout the world. International meetings, therefore, are vital to the growth and development of the field. Between 1976 and 1984 there were a series of Advanced Study Institutes and Workshops on plant molecular biology organized under the sponsorship of NATO and FEBS. These meetings in Strasbourg, Edinburgh, Portese, and Renesse were truly international and were of extraordinary importance in the development of the field, but they were restricted to 250 participants. The exponential growth in the numbers of disappointed applicants was a primary stimulus to the launching of the International Society for Plant Molecular Biology and the scheduling of the First Congress in Savannah, Georgia, USA, in November 1985.

The meeting in Savannah provided an opportunity for everyone with an interest in plant molecular biology to present his or her research, meet like-minded colleagues from around the world, and hear the leaders of the ficld in plenary sessions. The success of the First Congress with 2000 participants made clear the vital role to be played in our discipline by open, international meetings.

Now, three years and a million sequenced nucleotides later, the Second Congress is nearly upon us. The central section of this issue of the Reporter contains the Second Circular of the Congress including the scientific program, registration forms, and abstract forms. We should particularly note that 1 June 1988 is the deadline for the receipt of abstracts and of pre-registration at the reduced rate.

\section{Gene Nomenclature}

Until a few short months ago I should have thought that the names given to plant genes would be well down on the list of subjects likely to provoke controversy. Politics, sex, and religion were the adrenurgic warhorses of my youth. I led a sheltered life largely preoccupied with plastids, all very prokaryotic. The big boys never told me about gene nomenclature. Then Rick Hallick suggested that the Reporter should publish lists of cloned plant genes. It seemed 


\section{Appointments}

Michel Dron

Professor of Molecular Phytopathology

Institut de Biologie Moléculaire Végétale

Orsay, France

Anne Simon

Assistant Professor

Department of Plant Pathology

University of Massachusetts

Amherst, Massachusetts, USA

Hallick and Warwick Bottomley (1983), is identical wherever feasible with the nomenclature of bacterial genes. A similar scheme for mitochondrial genes is presented by David Lonsdale and Chris Leaver in this issue of the Reporter starting on p. 14. Similar homologies exist amongst genes for seed reserve proteins in plants, but the names given to the corresponding genes typically reflect the trivial names assigned to the proteins many decades ago.

In future issues of the Reporter we shall explore existing systems of gene nomenclature in future issues of the Reporter along with proposals for creating a universal system that would be useful to geneticists and molecular biologists alike. We welcome suggestions, criticisms, and expressions of opinion. $\Omega$

\section{References}

Burnham, C.R., E.H. Coe, O.E. Nelson, E.B. Patterson, \& M.M. Rhoades. 1975. Revised genetic nomenclature for maize. Maize Genet. Coop. Newsletter 49:3-4.

Demerec, M., E.A. Adelberg, A.J. Clark \& P.E. Hartman. 1966. A proposal for a uniform nomenclature in bacterial genetics. Genetics 54:61-76.

Hallick, R.B., \& W. Bottomley. 1983. Proposals for the naming of chloroplast genes. Plant Molec. Biol. Report. 1:38-43. 
like an excellent idea, so I drew up a form and began looking at lists of plant genes: adh, Adh1, bz ${ }^{+}$, napin g, $G$, phy A, phy-1, rbcS, ssu . . Of course, I had seen these names before, but I had not really absorbed their significance, that there is no generally accepted system for the naming of plant genes. Many of the names follow the bacterial system of three lower-case letters followed by a capital letter (Demerec et al., 1966). Others are variants on this plan with numbers or capital letters. Hyphens are used freely. There are superscripts and subscripts. Sometimes a gene name and protein name are used interchangeably. Is it important? Compared to politics, sex, and religion, perhaps not, but if somc earnest investigator becomes interested in the gene for, let us say, sucrose synthetase in cotton, it should be possible for him to search the literature for the gene in other organisms without having to consult a Thesaurus or a rhyming dictionary.

Until a dozen years ago, genes were the concern of geneticists. A heritable character would be found and the discoverer would name it; maybe it would be located on a chromosome. The need for any system of gene names was rarely required; maize geneticists are a notable exception (Burnham et al., 1974), but they had no particular reason to be concerned with the names of genes in peas, much less yeast, Drosophila, or bacteria. With the development of molecular biology, however, the situation has changed profoundly. Genes can be identificd with varying degrees of certainty through a number of increasingly simple techniques: sequencing, northern blots, screening cDNA libraries. Plant molecular biologists today contend with hundreds of genes or simply uorfs for which no heritable character has yet been identified.

In addition to multiplying the numbers of identified genes, molecular biology has challenged existing systems of gene nomencalture (or the absence of such systems) by demonstrating homologies of genes across lines separating species, genera, families, and even kingdoms. The extraordinarily rapid progress in identifying most of the genes of chloroplast DNA has occurred precisely because of the similarity between many plastid genes and those of bacteria. Chloroplast genes coding for components of RNA polymerase and of ribosomal proteins, for example, were initially identified from similarities between the predicted amino acid homologies with the corresponding genes in $E$. coli. It is no accident therefore that the nomenclature for plastid genes, proposed in this journal by Richard Hallick and Warwick Bottomley (1983), is identical wherever feasi- 